\title{
The Effect of Jigsaw Technique in Reading Comprehension on Recount Text
}

\author{
Herman ${ }^{1}$, Juwita Kristina Sibarani ${ }^{2}$, Hilman Pardede ${ }^{3}$ \\ University of HKBP Nommensen (UHN) Medan, Indonesia \\ 1herman@uhn.ac.id
}

DOI : 10.37329/cetta.v3i1.413

\begin{tabular}{l}
\hline Keywords: \\
\hline Effect, jigsaw, \\
reading \\
comprehension, \\
recount text
\end{tabular}

\begin{abstract}
The objective of this research is to find out the effect of Jigsaw technique on reading comprehension at grade ten of SMA 4 Negeri Pematangsiantar. The research used descriptive quantitative research design by applying Quasi-Experimental design. In conducting this design, the subjects of the research were divided into two groups: experimental group and control group. The treatment is introduced only to the experimental subject. The experimental group is treated by using Jigsaw technique while the control group is treated without Jigsaw technique. The subject of this research was the grade ten students (X PMIA 4 and X PMIA 5) in SMA Negeri 4 Pematangsiantar. The researcher used mobile phone as instrument which recorded video teacher and students activity during teaching and learning process in the class.

The result of the research showed that in significance degree of $5 \%$, the value of $t$-observe $>t$-table that was $(5.55>1.669)$. It could be said that t-observe was higher than t-table. So, the null hypothesis is rejected while the alternative hypothesis is accepted. In other words it can be concluded that the application of Jigsaw teaching technique significantly affects the students' ability in reading comprehension of recount text at grade ten of SMA Negeri 4 Pematangsiantar.
\end{abstract}

\begin{tabular}{l} 
Kata Kunci: \\
\hline Dampak, Jigsaw, \\
Pemahaman \\
membaca, teks \\
recount
\end{tabular}

\begin{tabular}{l} 
Abstrak \\
\hline Tujuan dari penelitian ini adalah untuk mengetahui dampak dari \\
penggunaan teknik jigsaw terhadap pemahaman membaca siswa kelas \\
10 SMA Negeri 4 di kota Pematangsiantar. Penelitian ini \\
menggunakan metode penelitian berupa deskriptif kuantitatif dengan \\
menerapkan model quasi-experimental. Dalam menerapkan model ini, \\
subjek penelitian ini dibagi menjadi 2 kelompok yaitu kelompok control \\
dan kelompok experiment. Perlakuan (treatment) dilakukan hanya \\
terhadap subjek experiment. Perlakuan (treatment) diberlakukan \\
terhadap kelompok experiment dengan menggunakan teknik jigsaw \\
sedangkan kelompok control tidak diberlakukan perlakuan dengan \\
\hline
\end{tabular}


menggunakan teknik jigsaw. Subjek dari penelitian ini adalah siswasiswi kelas 10 (X PMIA 4 dan X PMIA 5) di SMA Negeri 4 Pematangsiantar. Para peneliti menggunakan telepon selluler sebagai alat untuk merekam aktivitas guru dan siswa selama proses belajar mengajar yang berlangsung di dalam kelas.

Hasil dari penelitian ini menunjukkan bahwa tingkat signifikan yaitu $5 \%$, nilai t-observe lebih besar dari t-table yaitu $5.55>1.669$. hal ini dapat diartikan bahwa $t$-observe lebih tinggi daripada $t$-table. Maka hipotesis nol ditolak sedangkan hipotesis alternative diterima. Dengan kata lain, penelitian ini menyimpulkan bahwa penerapan teknik mengajar jigsaw memberikan dampak signifikan terhadap kemampuan siswa dalam pemahaman membaca dalam teks recount untuk siswasiswi kelas 10 SMA Negeri 4 kota Pematangsiantar.

\section{Introduction}

Language is very essential for human being. It plays an important role in our life and society. It is used as tool of communication, which means language is a meaning of communication that is used to interact and to strengthen relationship, such as getting or giving information and also to express their idea or other activities. Sapir (1921) as cited in Herman (2014:2) define language is purely human and non-instinctive method of communicating ideas, emotions, and desires by means of a system of voluntarily produced symbols. It means that language is own of human only in which is acquired through learning, implemented in form of sounds, produced by human organ of speech in sentences realities. Thus, language can be communicated in spoken language, written language and gestures. In line with this, language must be learnt to communicate with others well.

In communicating with others well, there are many kinds of languages in all over the world, such as; English, Mandarin, French, Indonesia, etc. People need to learn another language in purpose to make a social relationship with other people in different places or countries. Most people in the world learn English as the international language. Some of them use English as the second language after their mother tongue as a need of communication in this globalization era.

In Indonesia, the position of English is as a foreign language, it means that English need to be learnt and taught in the school and even inuniversity. The government of Indonesia inserted English language in the school curriculum, because of importance of English nowadays. In learning English, the students should master the four language skills, they are; reading, listening, writing, and speaking. On this occasion, the researcher will focus to reading, because mastery reading skill is very important. Reading is a critical 
academic skill, one which is necessary for success in all academic domains. We know that all the test usually need ability to read a text. Nowadays, especially in National Examination (UN), our government put Higher Order Thinking Skills (HOTS) where the students not only able to read but also comprehend the text well. Comprehending the text can be said as reading comprehension. But, many students were fail in reading comprehension.

Meng (2010:501) stated that English reading has always been regarded as one of the main aims in English teaching in colleges and universities, because it can objectively reflect the students' abilities to acquire the language.Thus, reading is important because it can help students to gain new information in order to comprehend what they read and to increase their knowledge.

The problem above is in line to the researcher's experience in teaching practice in SMA Negeri 4 Pematangsiantar on September 2017, the researcher found the fact that the tenth grade of SMA Negeri 4 Pematangsiantar had problems with reading comprehension ina recount text. The students had difficulties to get main idea, and understood the vocabulary. They were also difficult in comprehending the recount text when they found unfamiliar word and spent too much time to translate it. Thus, the students were unable to understand what the text was about. Consequently, the students could not answer the questions based on the text. The average score was 55, it means that the students couldn't achieve the criteria minimum passing grade is 70 . Therefore, it can be concluded students had low reading comprehension in recount text.

To solve the problems above, there aremanytechniquescan be applied for teaching reading comprehension such as, Student Team Achievement Division (STAD), Main Mapping, Jigsaw, Problem Based Learning (PBL), etc. One of them is Jigsaw technique. Jigsaw technique is a cooperative learning model that consists of several member in one group that responsible for the lesson materials and be able to teach the topic to other member of group, by discussion activities which can help the students to be active in the class, such as; reading the text, hearing the teacher reading the text, get new of vocabulary (Hyland, 2008). Jigsaw method make it suitable for enhancing two essential and related teaching goals that contribute to reading comprehension: developing students' metacognitive awareness, and learning the content while teaching it to peers in the small group (Meng, 2010:501-504). 
By creating an achievement, that the students can make group work through the assignment until the member of group successfully understand the topic and answer it. Furthermore, Jigsaw reading technique gives the students become more comfortable, free to have discussion with their group, and have a new fresh situation in the classroom.

Based on the explanation above,the researcher assumes that Jigsaw technique is suitable way to motivate students in reading. By using Jigsaw technique, they acquire basic knowledge. So, the researcher will conduct a researchentitled "The Effect of Jigsaw Techniquein Reading Comprehension at Grade ten of SMA Negeri 4 Pematangsiantar".

\section{Method}

\section{Research Design}

The research design used in this research is descriptive quantitative research design by applying Quasi-Experimental design. In conducting this design, the subjects of the research were divided into two groups: experimental group and control group. This research method is used to describe variables, to examine relationships among variables and to determine cause-and-effect interactions between variables (Burns \& Grove, 2005:23).

The treatment is introduced only to the experimental subject after measuring the two groups. The experimental group is treated by using Jigsaw technique while the control group is treated without Jigsaw technique. The test is given for each group and the average differences score are compered in order to certain whether the experimental treatment produce the greater change then the control group.

Table 1 Research Design

\begin{tabular}{|c|c|c|c|}
\hline GROUP & PRE-TEST & TREATMENT & POST TEST \\
\hline EXPERIMENTAL & $\sqrt{ }$ & $\mathrm{X}$ & $\sqrt{ }$ \\
\hline CONTROL & $\sqrt{ }$ & $\mathrm{Y}$ & $\sqrt{ }$ \\
\hline
\end{tabular}

Note:

$X \quad$ : using Jigsaw technique

Y : : using convensional technique 


\section{Population and Sample}

\section{a. Population}

According to Creswell (2012:381) the population is the group of individuals having one characteristic that distinguishes them from other group.The population of this research will be the students of SMA Negeri 4 Pematangsiantar at grade ten. There are 10 classes: 7 classes are X PMIA and 3 classes X PIS. Totalof population are 360 students.

\section{b. Sample}

According to Creswell (2012:381) the sample is the group of participants in a study selected from the target population from which the researcher generalized to the target population. The technique in deciding the sample is purposive sampling. Purposive sampling allows the researcher takes the sample by using their judgment to choose the appropriate sample for collecting the data that needed and usually based on the prior information. It was chosen because those samples have the purpose, make the researcher is easier in collect the data. The sample for this research is two classes, they are X PMIA 5 as the experimental class consists of 36 students, and X PMIA 4 as the control class consist 36 students.

\section{Research Instrument}

The instruments of this research are a test, camera recorder, and mobile phone. Test is a method to determine students' ability to complete certain tasks of a skill or knowledge content. Some types would be multiple choice tests, true-false tests, essay tests, etc. A test that the researcher will use in this research is multiple choice test. A multiple choice test is consist of twenty items. And the test taken from National Examination that have been standardized by government. The content of the test are to find mind idea, asking for general and specific information, finding the meaning or synonym of vocabulary, and chosing the right tenses to fill the blank. The researcher also will use camera recorder and mobile phone to record video when the researcher doing the process of collecting data.

\section{Technique of Data Collection}

In collecting the data, the researcher uses experimental and controlled class. The instruments that will be used to collect the data are: 


\section{a. Pre-test}

The researcher gave pre-test to both class; experimental and controlled class. The students were given some questions in the form of multiple choice based on the English text provided. The function of the pre test is to know the mean score of the control and experimental group before getting treatment.

\section{b. Treatment}

The experimental and control groups are taught by using the same material but different technique. In the experimental group, the teacher will apply Jigsaw technique. And in the control group, the teacher will apply a conventional method.

\section{c. Post- test}

Post-test was used to find out if Jigsaw technique is effective towards students' reading comprehension. The purpose of conducting the post-test is to find out the result of students' achievement after the students have been given the treatment in the form of teaching. The question test of post-test used was same as the question test used in pretest.

\section{The Procedure of Teaching}

\section{a. Teaching Process in Experimental Group}

\section{1) Pre-test}

Pre-test was given before the treatments. First, the researcher came to the class. Then, she explained to the students what they had to do. Finally, the distributed the instruments and asked them to do the test.

\section{2) Activities for Experimental Group}

Table 2 Teacher and Students Activities in Experimental Group

\begin{tabular}{|l|l|l|}
\hline No & \multicolumn{1}{|c|}{ Teacher } & \multicolumn{1}{c|}{ Students } \\
\hline 1 & $\begin{array}{l}\text { The teacher greets the students } \\
\text { and ask a student to lead pray }\end{array}$ & $\begin{array}{l}\text { The students greet the teacher and } \\
\text { a student lead a prayer }\end{array}$ \\
\hline 2 & $\begin{array}{l}\text { The teacher teaches about } \\
\text { recount text with the treatment: } \\
\text { Jigsaw technique }\end{array}$ & $\begin{array}{l}\text { The students' pay attention to } \\
\text { teacher explanation about recount } \\
\text { text }\end{array}$ \\
\hline 3 & $\begin{array}{l}\text { The teacher asks to make six } \\
\text { groups to apply Jigsaw technique }\end{array}$ & $\begin{array}{l}\text { The students' pay full attention and } \\
\text { responding what the teacher }\end{array}$ \\
\hline
\end{tabular}




\begin{tabular}{|l|l|l|}
\hline No & \multicolumn{1}{|c|}{ Teacher } & \multicolumn{1}{c|}{ Students } \\
\hline & $\begin{array}{l}\text { then they gave recount text to } \\
\text { identify generic structure, and } \\
\text { language features of recount text. } \\
\text { (Under teacher controlled). }\end{array}$ & instruction. \\
\hline 4 & The teacher gives a test & The students do the test \\
\hline
\end{tabular}

3) Post-test

Post-test was held after all treatment was conducted. The post-test is used to know the effect of Jigsaw technique in the experimental group. This test was used to measure students' achievement after they were given treatments. Then the post test is give to know the differences scores of group between the experimental and controls group.

b. Teaching Process in Contol Group

\section{1) Pre-test}

Pre-test was given before the treatment. First, the write came to the class. Then, she explained to the students what they had to do. Finally, she distributed the instruments and asked them to do the test.

\section{2) Activities for Control Group}

Table 3 Teacher and Students Activities in Control Group

\begin{tabular}{|l|l|l|}
\hline No & \multicolumn{1}{|c|}{ Teacher } & \multicolumn{1}{|c|}{ Student } \\
\hline 1 & $\begin{array}{l}\text { The teacher greets the students } \\
\text { and ask a student to lead pray }\end{array}$ & $\begin{array}{l}\text { The students greet the teacher and } \\
\text { a student lead a prayer }\end{array}$ \\
\hline 2 & $\begin{array}{l}\text { The teacher introduce the } \\
\text { material and explain about the } \\
\text { recount text }\end{array}$ & $\begin{array}{l}\text { The students are listened and pay } \\
\text { attention to the teacher explanation }\end{array}$ \\
\hline 3 & $\begin{array}{l}\text { The teacher give one example } \\
\text { about recount text }\end{array}$ & $\begin{array}{l}\text { The student listened to the teacher } \\
\text { explanation and giving response }\end{array}$ \\
\hline 4 & $\begin{array}{l}\text { The teacher ask the students to } \\
\text { analyze the recount text from the } \\
\text { example }\end{array}$ & $\begin{array}{l}\text { The students analyze the recount } \\
\text { text from the example }\end{array}$ \\
\hline 5 & Teacher gives the test & Students do the test \\
\hline
\end{tabular}




\section{3) Post-test}

Post test was held after all treatment was conducted. The post-test is used to know the effect of Jigsaw technique in the experimental group. This test was used to measure students' achievement after they were given treatments. Then the post test is give to know the differences scores of group between the experimental and control group.

\section{Scoring The Test}

In scoring the text, the researcher determined the cumulative score ranging from 0 100 by counting the correct answer and applying this formula.

$S=\frac{R}{N} \times 100$

Note:

S: Score

R: Correct answer

$\mathrm{N}$ : Number of test

100: Cumulative range 0 - 100

\section{Technique of Data Analysis}

To know the effect or result of the research, t-test formula was used to calculate. To analyze the data, the independent sample t-test is applied by using IBM SPSS 19.0. It is to analyze the possible different in writing composition between the two group involved in essay test. The procedure of analyze data using IBM SPSS 19.0 (Saragih, 2015:181)as follows:

a. Open the IBM SPSS 19.0 application.

b. Input the data

c. Click Analyze $\longrightarrow$ Compare Means $\longrightarrow$ Independent Sample T-Test

d. Input value variable to test variable (s) and group variable to Grouping variable then click Define Groups.

e. Type Experimental in group 1 column and control in Group 2 column then, click Continue $\longrightarrow \mathrm{Ok}$

f. The output will appear in two tables. Group statistic and Independent Sample Test.

g. Group statistic table to show data description which we analyze. The column which can be compared between two samples is Standard Deviation (Std. Deviation) column. 
It shows the difference of standard deviation of students' mark from two difference group.

h. Independent sample T-Test table is divided into two parts, such as Levene's Test for Equality of Variances (to test the homogeneity of variances ) and T-test for Equality of Means (to test mean difference)

i. In T-Test for Equality of Means column, if the result of $t_{0}>t_{t}$, it means that the students' average mark in experimental group is higher than in control group. It also shows that there is a significant effect of using Jigsaw Technique in reading comprehension recount text.

\section{Result and Discussion}

The researcher took the scores from the students both of the control and experimental class. Herewith, the researcher gives the report concerning the data description of students' score of pre-test and post test.

\section{The Pre-test Score}

In this section, the data obtained pre test of control class and experimental class. The pre test was taken on Thursday, 26thJuly 2018 at $09.00-10.30$ in class X PMIA 4 as control class and at $12.30-14.00$ in class X PMIA 5 as experimental class.Both of they were 36 students who followed this test. Table 4 report the students' score of pre-test.

Table 4 The Students' Score of Pre-test

\begin{tabular}{|l|l|l|l|}
\hline Students & $\begin{array}{l}\text { Pre-test Score of } \\
\text { Control Class }\end{array}$ & Students & $\begin{array}{l}\text { Pre-test Score of } \\
\text { Class }\end{array}$ \\
\hline APSS & 50 & AM & 20 \\
\hline APT & 25 & AS & 60 \\
\hline AP & 35 & BS & 45 \\
\hline AGN & 40 & CG & 30 \\
\hline DPS & 30 & DN & 20 \\
\hline DAS & 50 & DW & 60 \\
\hline CES & 45 & ETD & 45 \\
\hline FNS & 75 & EPS & 65 \\
\hline FNT & 65 & EYH & 65 \\
\hline
\end{tabular}




\begin{tabular}{|c|c|c|c|}
\hline Students & $\begin{array}{l}\text { Pre-test Score of } \\
\text { Control Class }\end{array}$ & Students & $\begin{array}{l}\text { Pre-test Score of } \\
\text { Experimental } \\
\text { Class }\end{array}$ \\
\hline GVUAS & 50 & FAN & 30 \\
\hline GS & 70 & GS & 65 \\
\hline GSW & 50 & GS & 45 \\
\hline GA & 50 & HT & 75 \\
\hline JCP & 50 & IMES & 65 \\
\hline JS & 40 & $\mathrm{JP}$ & 40 \\
\hline KM & 45 & JS & 50 \\
\hline KS & 45 & JD & 55 \\
\hline $\mathrm{LH}$ & 45 & KS & 60 \\
\hline MWS & 60 & $\mathrm{KN}$ & 45 \\
\hline MHS & 45 & LMS & 30 \\
\hline MABB & 45 & MG & 45 \\
\hline $\mathrm{MH}$ & 65 & MSG & 50 \\
\hline $\mathrm{MH}$ & 55 & NMM & 75 \\
\hline PAP & 55 & NSS & 70 \\
\hline RBD & 70 & NS & 20 \\
\hline $\mathrm{RN}$ & 65 & $\mathrm{OP}$ & 25 \\
\hline RF & 55 & OMG & 60 \\
\hline $\mathrm{RH}$ & 25 & RET & 50 \\
\hline SS & 60 & $\mathrm{RS}$ & 55 \\
\hline $\mathrm{SH}$ & 55 & SP & 45 \\
\hline SS & 55 & SS & 35 \\
\hline $\mathrm{TP}$ & 55 & SIS & 60 \\
\hline TG & 70 & SBS & 30 \\
\hline VS & 70 & $\mathrm{TH}$ & 75 \\
\hline YS & 55 & TLA & 45 \\
\hline ZTP & 45 & YSS & 45 \\
\hline$\sum$ & 1865 & $\sum$ & 1755 \\
\hline Mean & 51,81 & Mean & 48,75 \\
\hline
\end{tabular}


The researcher using SPSS Aplication to analyse the data. These table presents the descriptive analysis based on the result of the pre-test score of the control class and experimental class.

Table 5 The Descriptive Analysis of Pre-Test Scores of the

Control Class and Experimental Class

Statistics

Pretest Control Class

\begin{tabular}{|l|l|}
\hline N Valid & 36 \\
Mean & 51,8056 \\
Median & 50,0000 \\
Std. Deviation & 12,42996 \\
Minimum & 25,00 \\
Maximum & 75,00 \\
Stm & 1865,00 \\
\hline
\end{tabular}

Statistics

Pretest Experimental Class

\begin{tabular}{|l|l|}
\hline N Valid & 36 \\
Mean & 48,7500 \\
Median & 47,5000 \\
Std. Deviation & 16,14112 \\
Minimum & 20,00 \\
Maximum & 75,00 \\
Sum & 1755,00 \\
\hline
\end{tabular}

The above table shows the students' pre-test score of control class and experimental class. The test was given in the first meeting before giving any treatment. The researcher found that the control class has 25 as the minimum score and the experimental class has 20. Both of control class and experimental class has 75 as the maximum score. The mean score of control class is 51,80 and the experimental class is 48,75 . Hence, it can be concluded that the pre-test score of the experimental class is lower than the control class.

\section{The Post-test Score}

Table 6 reports the students' post test score of control and experimentalclass. The post test was taken on Thursday, 2ndAugust 2018 at 09.00 - 10.30 in class X PMIA 4 as control class and at $12.30-14.00$ in class X PMIA 5 as experimental class. They were 36 students who followed this test.

Table 6 The Students' Score of Post-test

\begin{tabular}{|l|l|l|l|}
\hline Students & $\begin{array}{l}\text { Post-test Score of } \\
\text { Control Class }\end{array}$ & Students & $\begin{array}{l}\text { Post-test Score of } \\
\text { Experimental } \\
\text { Class }\end{array}$ \\
\hline APSS & 65 & AM & 70 \\
\hline
\end{tabular}




\begin{tabular}{|l|l|l|l|}
\hline Students & $\begin{array}{l}\text { Post-test Score of } \\
\text { Control Class }\end{array}$ & Students & $\begin{array}{l}\text { Post-test Score of } \\
\text { Experimental } \\
\text { Class }\end{array}$ \\
\hline APT & 50 & AS & 80 \\
\hline AP & 50 & BS & 75 \\
\hline AGN & 60 & CG & 75 \\
\hline DPS & 50 & DN & 70 \\
\hline DAS & 60 & DW & 85 \\
\hline CES & 55 & ETD & 70 \\
\hline FNS & 85 & EPS & 90 \\
\hline FNT & 75 & EYH & 80 \\
\hline GVUAS & 60 & FAN & 70 \\
\hline GS & 75 & GS & 85 \\
\hline GSW & 70 & GS & 75 \\
\hline GA & 55 & HT & 80 \\
\hline JCP & 55 & IMES & 80 \\
\hline JS & 65 & JP & 70 \\
\hline KM & 55 & JS & 70 \\
\hline KS & 60 & JD & 75 \\
\hline LH & 50 & KS & 85 \\
\hline MWS & 70 & KN & 80 \\
\hline MHS & 60 & MMS & 70 \\
\hline MABB & 70 & NMM & 70 \\
\hline MH & 75 & NSS & 90 \\
\hline MH & 70 & NS & 75 \\
\hline PAP & 60 & OP & 70 \\
\hline RBD & 75 & 85 \\
\hline RN & 85 & 80 \\
\hline RF & 70 & 75 \\
\hline RH & 45 & 50 \\
\hline SS & 70 & 50 \\
\hline
\end{tabular}




\begin{tabular}{|l|l|l|l|}
\hline Students & $\begin{array}{l}\text { Post-test Score of } \\
\text { Control Class }\end{array}$ & Students & $\begin{array}{l}\text { Post-test Score of } \\
\text { Experimental } \\
\text { Class }\end{array}$ \\
\hline SS & 70 & SS & 80 \\
\hline TP & 70 & SIS & 70 \\
\hline TG & 80 & SBS & 90 \\
\hline VS & 85 & TH & 90 \\
\hline YS & 75 & TLA & 70 \\
\hline ZTP & 70 & YSS & 85 \\
\hline$\sum$ & 2380 & $\sum$ & 2780 \\
\hline Mean & 66,11 & Mean & 77,22 \\
\hline
\end{tabular}

The researcher using SPSS Aplication to analyse the data. These table presents the descriptive analysis based on the result of the post-test score of the control class and experimental class.

Table 7 The Descriptive Analysis of Post-Test Scores of the Control Class and Experimental Class

Statistics

Post test Control Class

\begin{tabular}{|l|l|}
\hline N Valid & 36 \\
Mean & 66,1111 \\
Median & 70,0000 \\
Std. Deviation & 11,15547 \\
Minimum & 45,00 \\
Maximum & 85,00 \\
Stum & 2380,00 \\
\hline
\end{tabular}

Statistics

Post test Experimental

Class

\begin{tabular}{|l|l|}
\hline N Valid & 36 \\
Mean & 77,2222 \\
Median & 75,0000 \\
Std. Deviation & 6,80803 \\
Minimum & 70,00 \\
Maximum & 90,00 \\
Sum & 2780,00 \\
\hline
\end{tabular}

Post test was given in the last meeting after the treatment. In the post-test, the minimum score of control class is 45 and the maximum score is 85. Besides, in experimental class the minimum score is 70 and the maximum score is 90 . The mean of the control class is 66,11 and the experimental class is 77,22 . Therefore, it can be seen that the post-test score of the experimental class is higher significant than the control class. 


\section{The Gained Score}

Table 8 below reports the gained score of the control class and the experimental class. Both control class and experimental class have 36 students.

Table 8 The Gained Score of Control Class and Experimental Class

\begin{tabular}{|c|c|c|c|}
\hline Students & $\begin{array}{l}\text { Gained Score of } \\
\text { Control Class }\end{array}$ & Students & $\begin{array}{l}\text { Gained Score of } \\
\text { Experimental } \\
\text { Class }\end{array}$ \\
\hline APSS & 15 & $\mathrm{AM}$ & 50 \\
\hline APT & 25 & AS & 20 \\
\hline $\mathrm{AP}$ & 15 & BS & 30 \\
\hline AGN & 20 & CG & 45 \\
\hline DPS & 20 & $\mathrm{DN}$ & 50 \\
\hline DAS & 10 & DW & 25 \\
\hline CES & 10 & ETD & 25 \\
\hline FNS & 10 & EPS & 25 \\
\hline FNT & 10 & EYH & 15 \\
\hline GVUAS & 10 & FAN & 40 \\
\hline GS & 5 & GS & 20 \\
\hline GSW & 20 & GS & 30 \\
\hline GA & 5 & HT & 5 \\
\hline $\mathrm{JCP}$ & 5 & IMES & 15 \\
\hline JS & 25 & JP & 30 \\
\hline KM & 10 & JS & 20 \\
\hline KS & 15 & JD & 20 \\
\hline $\mathrm{LH}$ & 5 & KS & 25 \\
\hline MWS & 10 & KN & 35 \\
\hline MHS & 15 & LMS & 40 \\
\hline MABB & 25 & MG & 25 \\
\hline $\mathrm{MH}$ & 10 & MSG & 25 \\
\hline $\mathrm{MH}$ & 15 & NMM & 5 \\
\hline PAP & 5 & NSS & 20 \\
\hline RBD & 5 & NS & 55 \\
\hline
\end{tabular}




\begin{tabular}{|l|l|l|l|}
\hline Students & $\begin{array}{l}\text { Gained Score of } \\
\text { Control Class }\end{array}$ & Students & $\begin{array}{l}\text { Gained Score of } \\
\text { Experimental } \\
\text { Class }\end{array}$ \\
\hline RN & 20 & OP & 45 \\
\hline RF & 15 & OMG & 20 \\
\hline RH & 20 & RET & 25 \\
\hline SS & 10 & RS & 15 \\
\hline SH & 30 & SP & 30 \\
\hline SS & 15 & SS & 45 \\
\hline TP & 15 & SIS & 10 \\
\hline TG & 10 & SBS & 60 \\
\hline VS & 15 & TH & 15 \\
\hline YS & 20 & TLA & 25 \\
\hline ZTP & 25 & YSS & 40 \\
\hline$\sum$ & 515 & $\sum$ & 1025 \\
\hline Mean & 14,30 & Mean & 28,47 \\
\hline
\end{tabular}

The researcher using SPSS Aplication to analyse the data above. These table presents the descriptive analysis based on the result of gained score of the control class and experimental class.

Table 9 The Descriptive Analysis of Gained Scores of the Control Class and Experimental Class

Statistics

Gained Experimental Class

\begin{tabular}{|lr|l|}
\hline $\mathrm{N}$ & Valid & 36 \\
Mean & & 28,4722 \\
Std. & Error $\quad$ of & 2,28712 \\
Mean & & \\
Std. Deviation & 13,72274 \\
Sum & & 1025,00 \\
\hline
\end{tabular}

Statistics

Gained Control Class

\begin{tabular}{|lr|l|}
\hline N & Valid & 36 \\
Mean & & 14,3056 \\
Std. & Error of & \\
Mean & & 1,12956 \\
Std. Deviation & 6,77735 \\
Stum & & 515,00 \\
\hline
\end{tabular}


The table data above describes that the gained score for the experimental class is higher that control class. The mean of gained score in control class is 14,30 and the experimental class is 28,47 .

\section{The T-test Score}

This section is intended to answer the research question whether Jigsaw technique effective on students' reading ability in comprehending recount text at grade ten of SMA Negeri 4 Pematangsiantar. T-test was used to answer the research question and conducted in both the experimental class and control class.

The researcher using SPSS Aplication to analyse the data to find out the t-test. These table presents the descriptive analysis of $\mathrm{t}$-test.

Table 10 The Descriptive Analysis of T-test

Independent Samples Test

\begin{tabular}{|c|c|c|c|c|c|c|c|c|c|c|}
\hline & \multicolumn{2}{|c|}{$\begin{array}{l}\text { Levene's } \\
\text { Test for } \\
\text { Equality of } \\
\text { Variances } \\
\end{array}$} & \multicolumn{7}{|c|}{ t-test for Equality of Means } \\
\hline & & \multirow[b]{2}{*}{$F$} & \multirow[b]{2}{*}{ Sig. } & \multirow[b]{2}{*}{$\mathrm{T}$} & \multirow[b]{2}{*}{ Df } & \multirow{2}{*}{$\begin{array}{l}\text { Sig. } \\
(2- \\
\text { tailed }) \\
\end{array}$} & \multirow{2}{*}{$\begin{array}{l}\text { Mean } \\
\text { Differen } \\
\text { ce }\end{array}$} & \multirow{2}{*}{$\begin{array}{l}\text { Std. } \\
\text { Error } \\
\text { Differe } \\
\text { nce } \\
\end{array}$} & \multicolumn{2}{|c|}{$\begin{array}{l}95 \% \text { Confidence } \\
\text { Interval of the } \\
\text { Difference }\end{array}$} \\
\hline & & & & & & & & & Lower & Upper \\
\hline ttest & $\begin{array}{l}\text { Equal } \\
\text { variances } \\
\text { assumed } \\
\text { Equal } \\
\text { variances } \\
\text { not } \\
\text { assumed }\end{array}$ & $\begin{array}{l}13,81 \\
9\end{array}$ & 000 & 5,554 & $\begin{array}{l}51,11 \\
5\end{array}$ & 000 & $\begin{array}{l}14,1666 \\
7\end{array}$ & 2,55085 & 9,07916 & 19,25418 \\
\hline
\end{tabular}

The calculation of t-test was used to test the hypothesis whether there was significant different between students' achievement in experimental class which was given Jigsaw technique and students' achievement in control class without using Jigsaw technique. Based on the table above, it is showed that the result of the t-test from the experimental class and control class is 5,55 . The table also showed that the degree of freedom (df) is 70 . The value level of significance is $0.05(5 \%)$ and $0.01(1 \%)$.

$t_{\text {table }}$ at $\mathrm{df} 70$ at $5 \%$ the level of significant $=1.669$

$t_{\text {table }}$ at $\mathrm{df} 70$ at $1 \%$ the level of significant $=2.385$ 
With the criteria:

If $t_{\text {test }}\left(t_{\text {observed }}\right)>t_{\text {table }}$, Ha is accepted and Ho is rejected.

If $t_{\text {test }}\left(t_{\text {observed }}\right)<t_{\text {table, }}$ Ha is rejected and Ho is accepted

Based on the result of hypothesis test calculation, it was found that the value of $t_{\text {observed }}$ was greater than the value of $t_{\text {table }}$ at the level of significance in $5 \%$ or $1 \%$ that was $1,669<5,55>2,385$. It meant Ha was accepted and Ho was rejected.

It could be interpreted based on the result of calculation that Ha stating that "the application of Jigsaw technique significantly affects the students' ability in reading comprehension ofrecount text" was accepted and Ho stating "the application of Jigsaw technique does not significantly affect the students' ability in reading comprehension ofrecount text" was rejected. It meant that teaching reading by using Jigsaw technique increases the grade ten students' reading scores at SMA Negeri 4 Pematangsiantar.

Based on the result of the data analysis above, the researcher found that the use Jigsaw technique is good to improve the students' reading comprehension ability. First, from the pre-test result, it can be gathered two findings, the mean of experimental group and the mean score of the control group, the mean score of the experimental group is 48.75 while the mean score of the control group is 51.81 . Both of those mean score are in the same category. From these results, it can be interpreted that the students of both groups are possessing equal intelligence. Second, based on the result of the post-test, it is found that there is an increase of the mean score of the experimental group and the control group. Nevertheless the increase of the mean score of the experimental group is higher than that of the control group. The increase of the mean score of the experimental group is 28.47 points. Meanwhile, the increase of the mean score of the control group is 14.30 points. The last, according to the result of hypothesis test calculation, it was found that the value of $t_{\text {observed }}$ was greater than the value of $t_{\text {table }}$ at $5 \%$ and at $1 \%$ the level of significance or $1,669<5,55>2,385$. It meant that Ha was accepted and Ho was rejected.

Based on the research analysis the use Jigsaw technique is good to improve the students' reading comprehension ability. The students are forced to understand the whole content of the text. The students are forced to analyze the specific information, the purpose, the topic, the main idea, etc of the text. The students also have to understand the context of the text. They have the responsibility to explain what they get to their friends. Unconsciously the students will be familiar on comprehending the text. The results were similar with the previous research done by Septami, et.al (2018) which was using the 
analytical exposition text. In Septami et.al's article, the jigsaw used was by the theory of Holliday (2002) which presents the nine procedures of jigsaw IV technique, meanwhile this theory used different theory. The location selected in the article was in SMAN 2 Pekanbaru. The results of the study showed that there are good effects of Jigsaw IV technique and solved the second year students' problem on reading comprehension especially towards students' reading comprehension of SMAN 2 Pekanbaru. It is suggested that Jigsaw IV technique can be applied not only for junior high school level, undergraduate students level, EFL students level, and students in science class but also can be applied for second year of senior high school level. In short, the jigsaw technique is really useful and beneficial for English teacher in teaching English especially related with a skill of writing in a genre.

\section{Conclusion}

Based on the result of the analysis, it showed that in significance degree of $5 \%$, the value of $\mathrm{t}$-observe $>\mathrm{t}$-table that was $(5.55>1.669)$. It could be said that $\mathrm{t}$-observe was higher than t-table. So, the null hypothesis is rejected while the alternative hypothesis is accepted. In other words it can be conclued that the application of Jigsaw teaching technique significantly affects the students' ability in reading comprehension ofrecount text at grade ten of SMA Negeri 4 Pematangsiantar.The contribution after the researcher applied the Jigsaw technique is the students more understanding purpose of the recount text, the structure of the recount text, and the linguistic element of recount text. And also the students more aware about their responsibilities, because by using Jigsaw technique they are not only as students/listener but also as a teacher/expert.

\section{References}

Ary, D. (2010). Introduction to research in education. Belmont, CA: Davis.

Boardman, A., K, J. K., and Vaughn, S. (2008). Teaching reading comprehension to students with learning difficulties. New York: The Guilford Press.

Brassell, D. (2008). Enhancing English as a second language students' vocabulary knowledge. Journal of Reading, Vol. 8, No. 1. The Reading Matrix Founded.

Burns, N. \& Grove, S. K. (2005). The practice of nursing research: Conduct, critique, and utilization (5th ed.). St. Louis: Elsevier Saunders. 
Creswell, J. W. (2012). Planning, conduct, and evaluating quantitative and qualitative rresearch. Boston: Pearson.

Herman. (2014). An experiential function on students' genre of writing. Jakarta: Halaman Moeka Publishing. ISBN: 978-602-269-088-7

Hyland, K. (2008). Cooperative Learning, Success for All, and Evidence - based Reform in education. Éducation et didactique, Vol. 2, No. 2, pp.151-159. Varia.

Meng, J. (2010). Jigsaw cooperative learning in english reading. Journal of Language Teaching and Research, Vol. 1, No. 4, pp. 501-504. Finland.

Saragih, S. (2015). Aplikasi SPSS dalam statistic penelitian pendidikan. Medan: Perdana Publishing. 